
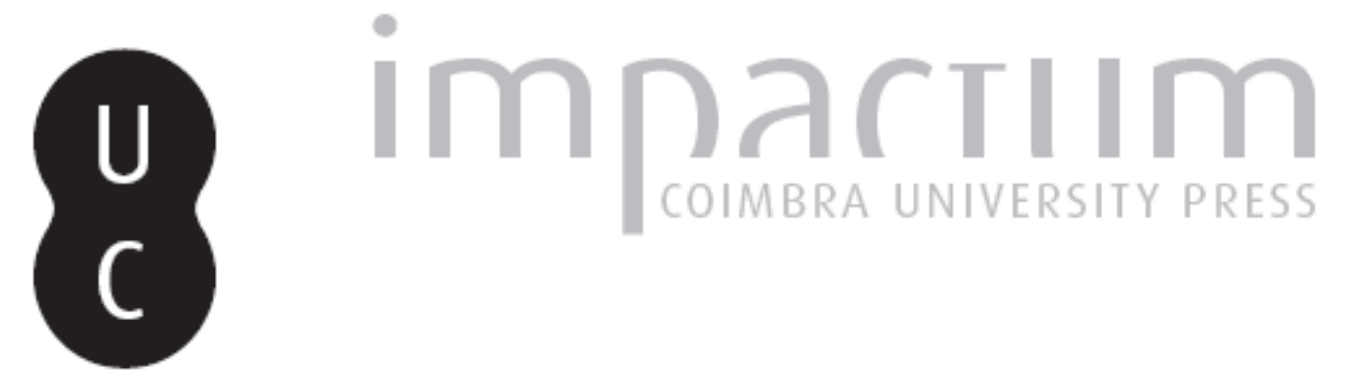

\title{
Antilogías sofísticas en Plutarco: sobre el demon de Sócrates
}

Autor(es): Durán López, M. a de los Ángeles

Publicado por: International Plutarch Society

URL persistente:

URI:http://hdl.handle.net/10316.2/37607

DOI:

DOI:http://dx.doi.org/10.14195/0258-655X_3_3

Accessed : $\quad$ 26-Apr-2023 09:13:23

A navegação consulta e descarregamento dos títulos inseridos nas Bibliotecas Digitais UC Digitalis, UC Pombalina e UC Impactum, pressupõem a aceitação plena e sem reservas dos Termos e Condições de Uso destas Bibliotecas Digitais, disponíveis em https://digitalis.uc.pt/pt-pt/termos.

Conforme exposto nos referidos Termos e Condições de Uso, o descarregamento de títulos de acesso restrito requer uma licença válida de autorização devendo o utilizador aceder ao(s) documento(s) a partir de um endereço de IP da instituição detentora da supramencionada licença.

Ao utilizador é apenas permitido o descarregamento para uso pessoal, pelo que o emprego do(s) título(s) descarregado(s) para outro fim, designadamente comercial, carece de autorização do respetivo autor ou editor da obra.

Na medida em que todas as obras da UC Digitalis se encontram protegidas pelo Código do Direito de Autor e Direitos Conexos e demais legislação aplicável, toda a cópia, parcial ou total, deste documento, nos casos em que é legalmente admitida, deverá conter ou fazer-se acompanhar por este aviso.

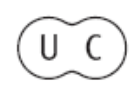




\section{PLOUTARCHOS, n.s.}

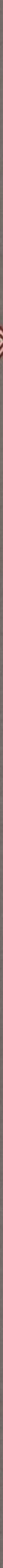

UNIVERSITY OF MÁLAGA (SPAIN)

UtAH STATE UNIVERSity, LOGAN, UTAH (U.S.A.) 


\title{
Antilogías sofísticas en Plutarco* ( Sobre el demon de Sócrates) por \\ Ma de los Ángeles Durán López \\ Universidad de Málaga
}

\begin{abstract}
Plutarch's use of antilogy is obviously influenced by rhetorical patterns of his age; however, his ethical and didactical training has closest affinity with the use of oldest Sophists. For these, the antilogy is a rational method, adequate to determine the con venient choice facing a dilemma. This presupposition gives a base to study Plutarch's use of antologica! patterns in The Genius of Socrates.
\end{abstract}

I.- Las antilogías. Su importancia en la estructuración de los tratados de Plutarco.

Aunque el uso de las antilogías sea, indudablemente, tan antiguo como el del propio lenguaje, para muchos de noso tros este término reclama con frecuencia el epíteto de sofística. La asociación no es gratuita ya que no sólo responde al abundante uso de este procedimiento por parte de los sofistas y, dada la cicatería que ha mostrado la tradición en la trans misión de los textos de la Sofística, sobre todo, por parte de los autores influidos por ellos como Tucídides y
Eurípides, sino también, porque es a uno de los primeros sofistas, Protágoras de Abdera, a quien debemos la teoría que da cuenta de la naturaleza de la antilo gía. La atención que presta a este modo de organizar los argumentos revela que veía en él algo más que un simple recur so retórico; sabemos, en efecto, que, aunque no fuera el propio Protágoras quien les diera estos títulos, una de sus dos grandes obras, la que corresponde al nivel crítico del pensamiento del autor ${ }^{1}$, se llamaba, precisamente, Antilogías; la otra que corresponde al momento cons tructivo, se conoce bajo los nombres de la Verdad, los Discursos Demoledores y

Una versión preliminar de este trabajo fue presentada en el Encuentro de la Red Plutarco celebrado en Montpellier los días 29 y 30 de Septiembre de 2000.

Sobre los dos niveles de la doctrina de Protágoras, crítico el uno y constructivo el otro, que corresponden respectivamente a sus dos obras, véase M. Unstersteiner, I sofisti I, Milán, 19672 . 
el Gran Tratado ${ }^{2}$. Se admite hoy que las que, como obras independientes, enume ra Diógenes Laercio en IX 55 eran sec ciones de las mismas ${ }^{3}$. El resumen de la primera de estas obras, Antilogías, puede encontrarse en la concisa expre

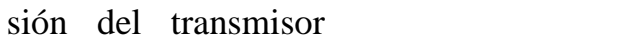

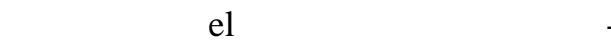

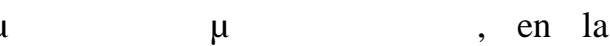
que suele verse, a un tiempo, la quintae sencia del relativismo protagórico y la clave de las antilogías.

Esta concisión tiene, sin embargo, un precio y es que oculta las relaciones de la antilogía con el dilema: coincide con éste en la exclusión de la síntesis a la que aspi ra la antítesis. Como el dilema, la antilo gía ignora la "armonía de los contrarios" en el Logos, que postulaba Heráclito, negando, por tanto, la posibilidad de neu tralización de los términos o argumentos opuestos. Buena prueba de la oposición exclusiva que la antilogía establece entre los extremos opuestos nos brinda el anó

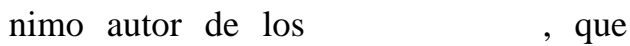
empieza la sección en que trata del bien y del mal con las palabras siguientes

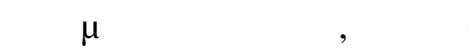
$\lambda o \quad \varepsilon v \dot{\varepsilon} \sigma \tau 1$ to $\alpha \gamma \alpha \theta \dot{\mathrm{o} \nu}, \dot{\alpha} \lambda \lambda \mathrm{o} \delta \varepsilon$

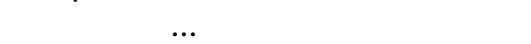

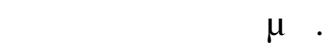

Insiste en esta misma idea en el pará grafo 11 donde precisa que difieren

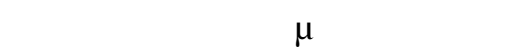

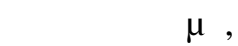

para concluir

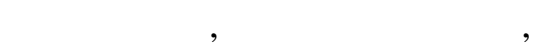

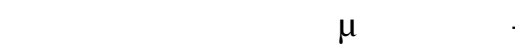

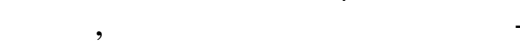

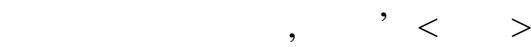

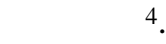

Argumentos paralelos encontramos con respecto a lo honroso y lo censura ble, lo justo y lo injusto, lo verdadero y lo falso. Similar es al respecto la postura del Anónimo de Jámblico en el que la antilogía entre la ev่vo i $\alpha$ y la $\alpha$ vo i $\alpha$ tiene ese mismo carácter dilemático. Todo esto induce a pensar que, pese a su rotundidad, el resumen de Diógenes Laercio requiere un complemento, ya

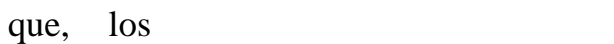

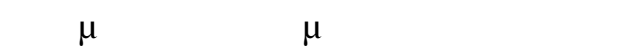
son sostenidos sobre un mismo objeto por personas diferentes o bien por una misma persona ante circunstancias dife rentes. Ejemplos protagóricos de lo uno y de lo otro encontramos en el Teeteto y en el Protágoras platónicos. En el pri mero de ellos Sócrates asume la defensa del sofista, que ya había muerto cuando tiene lugar esta supuesta conversación entre el filósofo y el joven que estaba

Es sabido que los antiguos no concedían gran importancia a los títulos de las obras en prosa; esto explica la diversidad de los nombres de su segunda obra a tenor del aspecto que los lectores consideraban relevante. DK 80 A 1.

$4 \quad$ DK $90,1,1 ; 11 ; 17$. 
llamado a ser el matemático más impor tante de su época. Defendiendo, pues, la tesis de que "verdad es para cada cual lo que percibe", Protágoras pone, por boca de Sócrates, el ejemplo del hombre sano y el enfermo que sostienen opiniones con tradictorias sobre la miel, que el primero percibe dulce y el otro amarga ${ }^{5}$. Por su parte el Protágoras nos había mostrado a una misma persona sosteniendo opiniones contradictorias sobre un mismo objeto, porque toma en cuenta diferentes circuns tancias. Se trata del conocido pasaje en el que el sofista se niega a admitir, sin más, la identificación de lo bueno y lo útil, por que, constata, hay cosas que no son útiles para los hombres, pero sí para los caba llos, o que no lo son para los animales y sí para las plantas, etc. ${ }^{6}$.

Expresiones similares son, evidente mente, frecuentes fuera de los fragmen tos sofísticos y de las autores influidos por ellos; en estos casos pueden respon der al uso espontáneo del lenguaje o bien a una utilización consciente de los recursos retóricos, promovida por las teorías de los sofistas y aceptadas en el plano formal incluso por quienes no aceptaban su puntos de vista epistemoló gicos, políticos o morales. Como ejem plo podemos mencionar la paradójica afirmación de Antigona

$$
\text { eireí ye } \delta \dot{\tau} \tau \eta \nu ~ \delta v \sigma \sigma \varepsilon \dot{\beta} \beta^{\wedge} 1 \alpha \nu
$$

\section{$\beta \dot{\sigma \varepsilon} \beta \circ \ddot{\cup} \sigma^{\prime} \dot{\varepsilon} \kappa \tau \eta \sigma \dot{\alpha} \eta v^{7}$}

en la que constata que ha violado la ley positiva con la misma acción con la que cumplía lo dispuesto por las Leyes no escritas. Para el caso dado al menos, uno y otro código son criterios en los que se basan dictámenes contradictorios sobre una misma conducta.

Todos estos ejemplos revelan que la antilogía considera desde un punto de vista teórico la misma disyuntiva entre dos alternativas que se excluyen mutua mente en el dilema cuando las conside ramos desde el punto de vista de la deci sión de actuar.

La dicotomía básica que hemos visto en la tesis de Protágoras y en los ejem

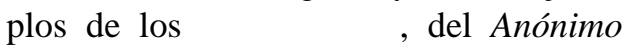
de Jámblico o en la Antigona subsiste en las Tetralogías de Antifonte y en los numerosos pasajes de obras de Teatro y en los discursos de la Historia de Tucídides que responden a esa misma estructura. La diferencia es que en estos otros casos la defensa de cada uno de los

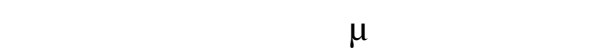
cuenta con dos turnos. En otros casos la antilogía básica se complica por la pre sencia de un tercer término, que no es síntesis de los dos primeros, sino que cada uno de ellos se opone, en oposición exclusiva, a los otros dos. Ejemplos

\footnotetext{
5

Platón, Teeteto 166 d-167.

6 Platón, Protágoras 333 d.

7 Sófocles, Antigona 923-924
} 
conocidos de esta situación son el famo so debate sobre las constituciones políti cas en el tercer libro de la Historia de Heródoto, el relato que hace Tucídides del debate sobre Mitilene o la discusión, refe rida por Plutarco en su Vida de Feríeles, entre el estadista y el sofista Protágoras sobre un accidente ocurrido en una pales tra: cuenta el biógrafo que estuvieron todo un día considerando si era culpable, el joven que disparó la jabalina, ésta o los jueces de la competición ${ }^{8}$.

Las escuelas de Retórica, herederas a la postre de los sofistas tanto en el obje tivo de preparar a los futuros políticos para salir airosos ante la asamblea y ante los tribunales como en los procedimien tos formales recomendados en cada situación, recurrieron constantemente a las antilogías, pero, al convertirlas en ejercicio escolar, las fueron sometiendo a un esquematismo tan rígido que, cuan do llegamos a la época de Plutarco, la antilogía da la impresión de haber que dado fosilizada, de haber sido despojada de su esencial vinculación a la realidad de la vida. Apunta ahora prioritariamen te a alardes de virtuosismo de los que cabe esperar toda clase de excesos. Inevitablemente, Plutarco tuvo que que dar marcado por las reglas imperantes en su tiempo ${ }^{9}$, y, de hecho, es fácil encon trar ecos de las mismas en los tratados considerados de juventud, que, en más de una ocasión, se atribuyen precisa mente a esta etapa por su excesiva fide lidad a las recetas y fórmulas escola res ${ }^{10}$. Es igualmente fácil constatar que la estructura de varios de esos tratados responde a un planteamiento antilógico, evidente cuando se refleja incluso en el título. Así ocurre en La fortuna o la vir tud de Alejandro, en Sobre la virtud y el vicio $^{\mathrm{n}}$, en Sobre el adulador y el amigo, etc. En otros desaparece del título pero subsiste en el contenido, por ejemplo en el tratado Sobre la gloria de los atenien-

$x$

Heródoto, III, 80-82; Tucídides, III, 36-48; Plutarco, Feríeles, 36, 5.

9

Referencias obligadas en este aspecto son F. Krauss, Die rhetorischen Schriften Plutarchs und ihre Stellung im plutarchischen Schriftencorpus, Nuremberg, 1912 y las columnas que E. Ziegler dedica al estilo en su "Plutarchos von Chaironea", $R$. E., 1951, cois. 636-692, A. Barigazzi, "Plutarco e il dialogo 'drammatico', Prometheus 1988. 2, 141- 163 e I. Gal1 o, "Strutture letterarie del Moralia di Plutarco: Aspetti e problema" en J. A. Fernández Delgado y F. Pordomingo Pardo (eds.), Estudios sobre Plutarco: Aspectos formales, Madrid, 1996, pp. 3-16. Coinciden estos autores en admitir la distinción en la obra del queronense de una primera fase menos original, escolástica y retórica, y otra pos terior, más personal, y en advertir que la influencia retórica persiste en la época de madu rez, si bien los recursos, esquemas $\mathbf{y}$ figuras son ahora objeto de un uso más parco y, sobre todo, son seleccionados en función del carácter y del objetivo de cada tratado.

Cf., por ejemplo, F. Frazier, "Notice a La Fortune des Romains" en Plutarque. Oeuvres Morales, T. V. 1, París, 1990, pp. 15-17, sobre los problemas de datación de este tratado. 
ses en el que Plutarco se pregunta si son los escritores -historiadores, poetas trá gicos y oradores- o los hombres de acción -generales y políticos- los que más han contribuido a la gloria de Atenas; o, también en Sobre la fortuna de los romanos, porque, aunque no desarro lla más que la aportación de Túxn a la prosperidad de Roma, no puede excluirse la presencia de una organización antilógi ca $^{12}$; a favor de ella aboga la introducción del tratado, que empieza con la descrip ción de la Virtud y de los héroes que la escoltan. Cierto es que faltan los alegatos que pudieran hacer de contrapeso a los testimonios a favor de la Fortuna, ausen cia que alimenta la polémica entre quienes piensan que la redacción de este tratado quedó interrumpida antes de ceder la pala bra a los testigos de la primera y quienes suponen que ésta debía ser objeto de un tratado independiente. En todo caso queda claro que tanto una como otra opción implica un fondo antilógico.

De todos modos, el recurso a la anti logía no es exclusivo de los tratados de juventud. Aparece igualmente en otros varios tratados de distinta época, como Sobre la superstición, que, de hecho, opone superstición y ateísmo, el Erótico, que opone amor homosexual y heterose xual, Sobre la inteligencia de los anima les, donde opone animales terrestres $\mathrm{y}$ animales acuáticos, etc. Al mismo tiem po hemos de tener en cuenta que una misma antilogía puede estar en la base de más de un tratado: entre los que aca bamos de mencionar, la que gira sobre la oposición entre la virtud y la buena suer te sustenta la estructura de Sobre la vir tud o la fortuna de Alejandro y se deja entrever en Sobre la fortuna de los romanos tanto si el desarrollo sobre la virtud pertenecía a este tratado como si constituía el tema de otro independiente, en cuyo caso la antilogía quedaría esta blecida entre ambos. También es fácil constatar que una antilogía esencial en uno o varios tratados puede volver a aparecer como tema secundario o margi nal en otros; por ejemplo, esa misma antilogía entre la virtud y la suerte es recurrente en Sobre el demon de Sócra tes, donde aparece ya en el prólogo cuando Arquédamo, en la intervención con la que inicia el tratado, justifica la atención que un lector $\varphi 1 \lambda$ ótı ov $\kappa \alpha$ ! $\varphi 1 \lambda$ óк $\alpha \lambda$ ov presta a los detalles de los

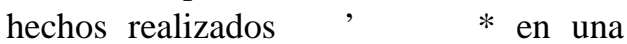
doble consideración: la primera es que en el resultado final de una empresa no es infrecuente que haya sido decisiva la influencia de $\tau \dot{x} \chi \eta$, mientras que, por el contrario, la segunda postula que las causas y detalles del proceso de dicha empresa reflejan los combates de la vir-

12

Los distintos valores de $\tau \dot{u} x \eta$ han sido estudiados por F. Mestre y P. Gómez en "Tyche e individuo: ambigüedad de usos en las Vidas Paralelas de Plutarco", en A. Pérez Jiménez y F. Tt it chener, Valori Letterari delle Opere di Plutarco, Málaga-Logan, 2005, pp. 295-306. 
tud frente a los golpes de suerte y la resolución de las $\tau$ 七o $\lambda \dot{\alpha} * \dot{\varepsilon} \varphi \rho o v \alpha * \tau o v$ $\lambda$ oyı $1 \sigma$ ov frente a las circunstancias y las pasiones. Más adelante, en 578 A, encon tramos la versión negativa de esa misma antilogía, que se plantea ahora entre el deli to y la mala suerte. Se trata de la observa ción que hace Fidolao a propósito de la profanación de la tumba de Alcmena, cuando precisa que los habitantes de Haliartes consideran que las calamidades que les han ocurrido -se les perdió la cose cha y se desbordó el lago Copáis- no se debieron a circunstancias fortuitas, sino al castigo divino por esa profanación.

Más aún, si tenemos en cuenta que el planteamiento antilógico preside tam bién las Vidas paralelas donde las per sonas cuyas vidas se emparejan quedan contrapuestas desde varios puntos de vistas a la vez; y que encontramos igual mente planteamientos antilógicos en las Cuestiones, en las que siempre se nos ofrecen como alternativas dos o más soluciones ${ }^{13}$, tendremos que admitir que la presentación antilógica de los temas constituye una característica del modo plutarqueo de estructurar sus escritos o, como dice G. D'Ippolito, un “elemento autotestuale fondamentale anche al live11 o di struttura profonda ${ }^{14}$ ".

Entre los rasgos comunes a La fortu na o la virtud de Alejandro, La fortuna de los romanos y La gloria de los ate nienses, querría destacar ahora uno que me parece relevante para distinguir el uso de la antilogía derivado de las escuelas de Retórica y el que de la mis ma hacían los sofistas de la época de Pericles: su divorcio de la vida en las escuelas frente a su vinculación con ella en los de época clásica. En efecto, en estos tres tratados Plutarco discute con gran erudición sobre hechos pretéritos: sobre si el éxito de Alejandro o la pros peridad de Roma se debieron a la suerte o a la valentía, prudencia, rectitud o, en una palabra, a la virtud del rey de Macedonia en un caso, de los gobernan tes y del pueblo de Roma en el otro. Sea cual fuere la causa, esos éxitos son lo que fueron y no admiten modificación alguna; el lector no puede intervenir. Acaso, si se debieran a la virtud, podría mos tomarlos como ejemplos e intentar imitarlos, pero incluso esa supuesta lec ción dista de ser evidente, porque no es fácil que las circunstancias de la vida de Alejandro se hayan de repetir en la de

13 Como excepción cabe mencionar la sexta Cuestión platónica que, pese a la evidente jerarquización formal de los argumentos, no propone realmente una alternativa entre dos

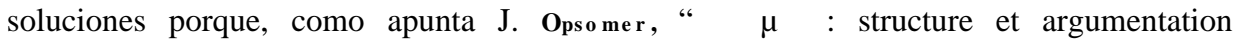
dans les Quaestionesplatonicaé" en J. A. Fernández Delgado y F. Pordomingo Pardo (eds.), Estudios sobre Plutarco: Aspectos formales, Madrid, 1966, pp. 71- 83, concreta mente, p. 79, Plutarco había creado artificialmente el dilema que plantea.

14 G D'Ippol it o, "Stilemi ilomorfici nel macrotesto plutarcheo", en J. A. Fernández Delgado y F. Po r do ming o Pardo (eds.), Estudios sobre Plutarco: Aspectos formales, pp. 23-24. 
cualquiera. Por supuesto, las grandes hazañas suscitan la admiración que Plutarco quiere provocar por medio de sus biografías; pero, al preferir este género a la pura historiografía el queronense demuestra, incluso en estos casos de horma escolar, su interés por vincular los hechos a la vida; con ello deja traslu cir la afinidad con las antilogías sofísti cas que podremos comprobar en otras obras, como el tratado Sobre el demon de Sócrates, que veremos más adelante.

La distancia entre los hechos conside rados y la actualidad del lector se percibe asimismo en el tratado Sobre la gloria de los atenienses: desde la Antiopa de Eurípides en adelante la discusión sobre la superioridad de las Armas o de las Letras se ha convertido en un tópico que envuel ve los argumentos esgrimidos en una sen sación de déjà $v u \backslash$ por ello, por esa sensa ción de estar ante tópicos manidos, el lec tor no se siente implicado; asiste al duelo verbal como a un espectáculo; aprecia la maestría, el brío o la elegancia de los argumentos, pero no cuenta con ellos para orientar el sentido de su vida. Por el con trario, las antilogías de los sofistas de antaño apuntaban a la acción y a la vida, a la decisión de adoptar una determinada conducta. Buena prueba de ello tenemos en el apólogo Heracles entre el vicio y la virtud de Pródico, cuya influencia en la descripción que hace Plutarco de los cor tejos de la Virtud y de Túxฤ en La fortu na de los romanos salta a la vista.

El apólogo de Pródico enfrentaba las personificaciones de la Virtud y el Vicio en un combate verbal, auténtico agon, en el que está en juego la voluntad del joven héroe al que quieren seducir y persuadir para arrastrarlo a su bando. Por eso, la oposición irreductible de las dos personi ficaciones, tan determinada la una como la otra, gira sobre el eje de la función impresiva, que domina ambos discursos. Consecuencia de ello es que, a pesar de la indiscutible divergencia de sus contenidos lógicos, si atendemos al objetivo pragmá tico que se proponen, ambos discursos po drían resumirse en los mismos términos: "Venga, muchacho, vente conmigo". Y, puesto que los sofistas utilizaban el mito como alegoría, ese joven Heracles que ha llegado al punto en que el camino se bifur ca, y que, si quiere seguir adelante, cami nando y viviendo, tendrá que decantarse necesariamente por uno u otro ramal, es ca da uno de nosotros; de modo que es a cada uno de nosotros a quien se dirigen las in sistentes llamadas de la Virtud y del Vicio, llamadas constantemente reiteradas por que, una vez tras otra, en cada paso que demos a lo largo de nuestras vidas, ten dremos que hacer esa inevitable elección.

Muy abundantes ejemplos de la rela ción que intento defender entre la antilo gía sofística y la vida proporciona el Teatro, un género que influyó en el pen samiento de algunos de ellos, notable mente en Gorgias, y fue muy claramente influido por los planteamientos de los sofistas. Al pasar a la escena la antilogía se incorpora en debates que preparan la decisión de acción e, incluso en los casos en que la discusión pasa a un plano indiscutiblemente teórico -por 
ejemplo, el agon entre Teseo y el heral do tebano en las Suplicantes de Eurípi des-, el drama se las arregla para inser tarla en la vida. No sería oportuno dete nernos ahora en esta cuestión, pero, en mi opinión, es evidente que, por ejem plo, el agon entre Creonte y su hijo Hemón en la Antigona de Sófocles reposa en un objetivo vital para cada uno de ellos: el rey quiere afirmar su autoridad y esta voluntad es la que le impide revo car su cruel decreto; está convencido de que el dejar sin efecto la sentencia de muerte de Antigona arruinaría la reputa ción de justicia en la que quiere asentar su reinado y, sobre todo, dejaría en en tredicho su autoridad. Por su parte, Hemón intenta producir en su padre una ac titud de mayor flexibilidad, único medio de conseguir salvar la vida de su prome tida y, en última instancia, también la su ya. De este modo, al insertarla en el eje de la oposición entre la Vida y la Muer te, la ironía trágica de Sófocles viene a refrendar la querencia de la antilogía por la acción y la vida. En cuanto a Eu rípides, conocida es su predilección por la composición de argumentos opuestos que lo llevan a utilizar con frecuencia antilogías para preparar la decisión de actuar. Ya hemos aludido a la Antiopa, cuyo argumento puede resumirse en una antilogía básica entre vida contemplati va y vida activa, y al debate entre Teseo y el heraldo tebano en las Suplicantes; podemos agregar ahora otros ejemplos de lámina, el debate entre los dos her manos, Etéocles y Polinices, al que se agrega, como tercer término, el parla mento de Yocasta en las Fenicias o bien los agones de Andromaca con Hermione y con Menelao en la Andrómaca, etc.

La comparación entre las antilogías escolares y las auténticas antilogías sofísticas nos permite comprender la im presión de rigidez y frialdad que provo can las primeras. Esta diferencia puede servimos de punto de partida para estu diar el juego de las antilogías imbricadas unas en otras en el tratado de Plutarco Sobre el demon de Sócrates ${ }^{15}$, un diá logo cuya acción compara el propio au tor con un drama ${ }^{16}$.
IL- Las antilogías en el tratado Sobre el demon de Sócrates.
El prólogo.

La prioridad concedida al plantea miento antilógico en esta obra se mani fiesta ya en el prólogo; éste comprende dos unidades esenciales: las palabras de Arquédamo que pide a Cafisias que le refiera con todo detalle la liberación de

15 Este tratado ha sido privilegiado dentro de la obra de Plutarco en cuanto al estudio de los aspectos formales. Cf. I. Ga 1 o , loe. cit., pp. 12 ss. y n. 22.

16 De genio 596 D-E. Una observación similar se encuentra en el prólogo del Erótico (749 A); en este diálogo las noticias de la acción, trátese del concurso de citaredos como de la boda de Bacon e Ismenodora- son comunicadas, como en el Teatro, por mensajeros al grupo de amigos que se ha retirado al Helicón para conversar. 
Cadmea y la respuesta de éste, que acce de a lo solicitado. A ello siguen dos puntualizaciones del primero cuyo objetivo es presentar al público que asiste a la conversación actual y explicitar los pre cedentes de los hechos rememorados.

La primera intervención de Arquédamo empieza con una comparación entre las posibles actitudes de quienes con templan un cuadro y las de quienes to man conocimiento de acciones heroicas. La estructura de ambos términos parece estrictamente simétrica ${ }^{17}$ * *; cada uno de ellos comprende una antilogía que es ampliada con una justificación, pero ésta sólo responde a la estructura antilógica anterior en el primer caso, mientras que en el segundo Arquédamo no desarrolla más que la segunda alternativa, cuyo desarro llo comprende, a su vez, dos antilogías imbricadas una en otra. Así tenemos

Término de comparación: los que contemplan un cuadro

Ia antilogía

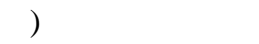

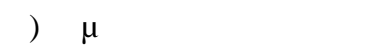

$2^{\text {a }}$ antilogía, amplificación y justificación de la anterior

a') ou่к $\alpha \kappa \rho 1 \beta \dot{~ \sigma u v o ́ \psi 1 ~}$

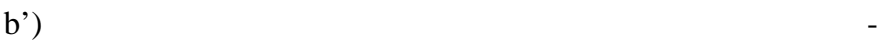

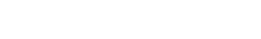

Término comparado: los que evalúan la exposición de hechos reales laantilogía

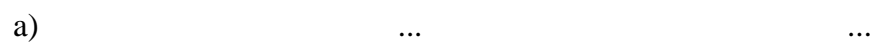
$\tau o \dot{v} \pi \rho \dot{\alpha} \gamma \alpha \tau \mathrm{O}$

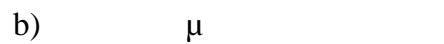

cuando contempla acciones heroicas disfruta con cada detalle.

$2^{\text {a }}$ antilogía, justificación de la opción b de la anterior

b. 1 porque en el resultado final interviene con frecuencia $\tau \dot{x} \times \eta$

b. 2 las causas y detalles tienen su propio carácter y reflejan

$3^{\mathrm{a}}$ antilogía, especificación de b 2

b. 2.1 los combates de la virtud frente a los golpes de suerte

b. 2. 2. las prudentes manifestaciones de audacia de la razón frente a

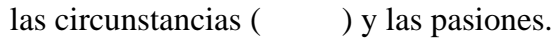

La afinidad entre antilogía y simetría viene de atrás, según J. Duc h e min, L'á $\gamma \omega v$ dans la tragédie grecque, Paris, 1945, de la práctica forense que concedía el mismo tiempo al acusador y al acusado; culmina en agones de Eurípides en los que atribuye exactamente el mismo número de versos a cada uno de los dos contendientes. 
Arquédamo concluye su solicitud con la aplicación al caso presente de la segunda opción, que es la preferida en cada una de antilogías anteriormente encadenadas y la explícita manifestación de lo solicitado: "cuéntanos cómo se desarrolló la hazaña desde el principio y haznos partícipes de la discusión".

La respuesta de Cafisias se apoya en esta solicitud; empieza por oponer la euyvoooiç y buena disposición de su amigo a una supuesta negativa a la beo $d a$ por su parte. Esta segunda posibili dad se convierte a continuación en la primera hoja de una nueva antilogía, cuya segunda opción es la negación de la supuesta $1 \sigma 0 \lambda$ oyia de los beocios, para lo que aduce como pruebas el para lelo de la presencia de Simias y Cebes junto a Sócrates y el del grupo de jóve nes beocios al que pertenece junto al santo Lisis ${ }^{18}$. Amén de la coincidencia en la $\varphi 1 \lambda \circ \lambda$ oyi $\alpha$ que demuestran los pri meros al atender los discursos del filóso fo ateniense y los actuales al escuchar los del sabio pitagórico, Cafisias está ponien do en paralelo Filosofía y Mística y, con ello, preparando la síntesis de ambas en el tema central de la discusión, el demon de Sócrates. El narrador termina su exposi ción anunciando un relato en el que van a coincidir la narración de los hechos histó ricos y el rapport de las conversaciones, como le había pedido Arquédamo.

El relato de Cafisias

El tratado de Plutarco Sobre el de mon de Sócrates reproduce la estructura del Fedón platónico en cuanto a la se cuencia de prólogo en el que un interlo cutor pide a un amigo que le refiera có mo se desarrollaron unos hechos y le dé cuenta de unas conversaciones que tu vieron ocasión entonces y el posterior relato de lo solicitado ${ }^{19}$; difieren en que, mientras que el diálogo platónico no plantea dudas sobre su contenido funda mental -la confianza de Sócrates ante la muerte abre cauce a una exposición sobre la inmortalidad del alma ${ }^{20}$-, el diálo go de Plutarco es objeto de una polémi ca sobre el objetivo fundamental del autor al escribir esta obra: Frente a quie nes piensan que la finalidad esencial es ensalzar a los tebanos al hacerlos simul tanear la gesta de la liberación de la ciu dad con el desarrollo de cuestiones filo sóficas, aunque éstas sólo se vinculen secundaria y superficialmente a la ac ción por la presencia de Teánor, se alza la opinión de quienes estiman que el de mon de Sócrates constituye el tema prin cipal del tratado, reduciendo la narra ción de los hechos históricos a mero arti ficio literario ${ }^{21}$; ambos puntos de vista
18

19

20

21

Acepto las correcciones de J. Ha n i.

Plutarco recurre a este mismo esquema compositivo en el De Pythiae y en el Erótico.

Fedón como el diálogo Sobre el alma.

Para una exposición detallada de estas opiniones, véase A. Corl u, Plutarque. Le démon de Socrate, París, 1970. 
resultan parciales y parece que no dan cuenta del pleno contenido del tratado en su matizada complejidad. Dejan la impresión de la necesidad de superar la antítesis entre la atemporalidad de las consideraciones filosóficas y la urgencia de la acción en la narración de los hechos históricos en una síntesis que A.

D. Stoike encontró en el tema de la liber tad, conseguida por la $\alpha \rho \varepsilon \tau \dot{\eta}$, que se afirma tanto para la ciudad como para las almas ${ }^{22}$. Tras él, otros estudiosos han intentado también sintetizar las dos ver tientes del tratado: M. Riley entiende que Sócrates es el punto en el que se establece la armonía entre los filósofos y los ciuda danos $^{23}$; A. Aloni, que destaca la contra dicción existente entre el discurso de Teánor y su defensa de la metempsícosis, encuentra la síntesis del tratado en la noción de una Providencia que lo abarca todo 24 ; D. Babut, por su parte, encuentra la clave en los tres grupos de hombres que, en su opinión, cabe distinguir en este tratado: aquellos cuyo perfecto dominio de las pasiones les autoriza a comunicar directamente con lo divino; los que, en el polo opuesto, quedan al margen de toda posible comunicación porque son escla vos de las mismas y, entre unos y otros, un grupo intermedio, al que corresponden los conjurados, cuyas virtudes no consiguen eliminar del todo sus pasiones y que, por ello, pueden quedar sorprendidos por los acontecimientos y fallar en sus prediccio nes ${ }^{25}$. En cuanto a A. Barigazzi, considera que Epaminondas es el personaje central que reduce a unidad el relato de los hechos históricos y la discusión sobre la influencia de los démones en la vida de los hombres; encuentra asimismo en la comparación ini cial entre los dos modos de ver un cuadro y la exposición de hechos reales ${ }^{26}$ la clave de la unidad entre la estructura intema y la es tructura formal del diálogo ${ }^{27}$.

Por mi parte, dado que el eco de Pla tón es casi una constante en los tratados de Plutarco, creo que no sería sorpren dente que también éste, en el que Só crates es el eje sobre el que gira el deba te filosófico que ocupa el centro del tra tado, pudiera ser interpretado en clave platónica, un punto de vista que, en cuanto a tiempo y lugar, está ya en el

A. D. St o ike, Plutarch's Theological Writings and Early Christian Literature, Leyde, 1975, pp. 236-245.

23 M. Ril e y, "The purpose and Unity of Plutarch's De genio Socratis", GRBS, 18 (1977) 257-273.

24 A. Al o ni, "Ricerche sulla forma letteraria del De genio Socratis di Plutarco", Acme, 33 (1980) 45-112.

D. Babut, "Le dialogue de Plutarque Sur le démon de Socrate. Essai d'interprétation", Bull. Bude, 1 (1984) 51-76 y Athenaeum, 62 (1984) 569-585.

27 A. Barigazzi, "Una nuova interpretazione del De genio Socratis", Illinois Classical Studies, 13 (1988) 409-425 y "Plutarco e il dialogo dramático", ant. cit. 
breve comentario que G. Anderson le dedica en su estudio sobre la segunda sofística ${ }^{28}$ Anderson ve en la situación histórica de la liberación de Cadmea el trasunto de la que se da en el Laques pla tónico donde los generales Laques y $\mathrm{Ni}$ cias dialogan con el trasfondo de la gue rra del arquidámica, mientras que las reuniones de los conjurados en casa de Simias, que no puede moverse por causa de una lesión en una pierna, corresponde a las visitas de sus amigos a Sócrates en la cárcel en el Fedón : "The scenario, then, is a Laches-cum- Phaedo in The bes ${ }^{29}$ ". En cuanto al contenido global, Anderson afirma: "the implication is that philosophy and statescraft are for men of action (though in fact Epaminon das advises restraint in this case)" $\mathrm{y}$, a renglón seguido, "Philosophy and his tory are made to alternate as the conspi rators vacillate and wonder whether they have escaped detection". Acepto la pri mera afirmación, aunque, como vere mos, la interpreto platonico modo; en cuanto a la segunda, me parece que ese trenzado de reflexión filosófica y urgen cia de la acción, que, efectivamente, puede reflejar los sobresaltos de los con jurados, admite una interpretación gene ral acorde con una de las características que el propio trabajo de Anderson ha despejado para los primeros siglos del Imperio: la doble vertiente de la activi dad de los autores de la Segunda sofísti ca, como literatos y como hombres de acción -en la medida en que el Imperio romano les daba margen para ello ${ }^{30}$ se refleja en la admiración de Dión de Prusa y de Amano por Jenofonte, el amigo de Sócrates que compaginó su participación en la expedición de los Diez Mil promo vida por Ciro el Joven con su dedicación a la literatura con pretensiones filosóficodidácticas; de hecho, las obras preferidas son la Anábasis y la Ciropedia ${ }^{31}$. Especialmente adecuada para iluminar la independencia que guardan entre sí las dos vertientes, histórica y filosófica, del tratado de Plutarco que comentamos me
Fundamentalmente embajadas, por lo general honoríficas. Cf. Anderson, loc. cit., p. 163. Las restricciones que el imperio romano imponía a la actividad política de los ciu dadanos griegos han sido tema recurrente en el VI congreso internacional de la IPS, donde fue abordado por L. De Bı o is, "Classical and Contemporary Statesman in Plutarch's Praecepta", M. Trapp, "Statesman in a Minor Key?", B. L. Cook, "Plutarch's "Many Other' Imitable Events: Mor. 814 B and the Statesman Duty", J. Boul og ne, "L’imaginaire politique De Plutarque" y por mí misma, "Plutarco, ciudada no griego y súbdito romano", Todas estas contribuciones han aparecido en L. De Bı ois, J. Boens, T. Kessels y D. M. Sschenkeveld, (eds.), The Statesman in Plutarch's Works, I, Leiden-Boston, 2004. 
parece la conclusión a la que llega Anderson sobre Marco Aurelio

We can examine three facets of his activities: his literary studies and friendly correspondence with Fronto; the private commonplace

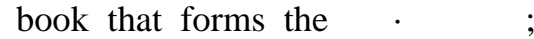
and the historical record of his legislation and responses to the problems of government. There is so little interaction among the three that it is fair to said that no-one could reasonably have inferred any one from either of the other $\mathrm{two}^{32}$.

Desde mi punto de vista, la relación entre el relato de la liberación de Cadmea y las reflexiones filosóficas podría com pararse con la que hay entre el hilo de la bobina y el de la canilla en un pespunte a máquina: las puntadas se suceden alter nando una y otra hebra. He preferido esta comparación a la que utiliza Platón en el Político de la relación entre la trama y la urdimbre en un tejido ${ }^{33}$ porque éste es una superficie, mientras que el pespunte es lineal y porque, al ser, a la vez, pro ducto de la alternancia de dos costuras simples encajadas la una en la otra, me parece más adecuado para reflejar el doble proceso de la progresión en la vida, uno, recurrente desde Hesíodo y Simónides, al que corresponde en el De genio el relato histórico y otro, el camino que, desde el poema de Parménides y desde la intuición platónica de la dialéctica como un proceso de ascensión, explica la adquisición del conocimiento como la progresiva superación de sus distintos grados; a este otro "camino" correspon den en el tratado de Plutarco las distintas fases del debate filosófico.

Decía que este tratado podría ser interpretado en clave platónica, en cuyo caso la síntesis que buscamos podría ser la respuesta de Plutarco a la pregunta esencial que Platón formulaba en el Gorgias, “Cómo hay que vivir para ser realmente feliz?". Cierto es que la beati tud que predica el filósofo en el Gorgias sólo puede alcanzarse después de la muerte, mientras que los personajes del tratado de Plutarco porfían por mejorar su situación en este mundo, pero entien do que su objetivo es apremiamos a encontrar los medios para transponer, como el filósofo que ha vuelto a la ca verna, las soluciones platónicas al mun do del devenir; a conseguir que la vida y la acción se ajusten, en la mayor medida posible, a la estructura que el espíritu contemplativo del filósofo encuentra fuera del tiempo. Tanto en el diálogo platónico como en el tratado de Plutarco esa respuesta se hace explícita en sendos mitos escatológicos, que difieren por su función - el del Gorgias repite las con clusiones a las que Sócrates había llega do en su discusión con Cábeles; su apor tación básica es de índole parenética. El del De genio, en cambio, suple aspectos

${ }^{32}$ Loe. cit., p. 179.

33 Platón, Político 283 a-b. 
esenciales en la explicación de la natura leza del alma que no había satisfecho el debate filosófico. Difieren también por la consideración del alma: el mito del Gorgias se basa en las consecuencias de la aplicación al alma de la doctrina ontológica de кóo o- $-\tau \alpha \xi_{1}$, que Platón inaugura en este diálogo, en razón de la cual la owppoøúvn interna que refleja la correcta proporción y organización del alma constituye su $\beta \dot{v}^{\wedge} \xi i \alpha$, mientras que

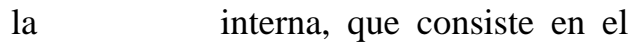
correcto funcionamiento del alma propor cionada y trabada en unidad, constituye su úvißı, su salud. En el De genio, en cam bio, la consideración del alma deriva de la que Platón expone en el Timeo, que es la única de las platónicas que Plutarco retie ne y en la que basa la suya propia ${ }^{34}$.

La oposición, a la que hemos aludido hace un momento, entre la atemporali dad de los temas tratados en las discu siones filosóficas y la actualidad de la praxis política es mencionada explícita- mente en el comentario de Cafisias al principio de su relato. Cuenta que los conjurados solían reunirse en casa de Simias para poner a punto sus planes y que, para disimular, daban a entender que el objetivo de esas reuniones era hablar de Filosofía. Con este mismo fin invitaban a veces a Arquias y a Leontíadas a sumarse a ellas. Comenta también que Arquias se alegraba al ver que los jóvenes se centraban en esas discusiones "en vez de preocuparse por lo que ellos (Arquias, Leontíadas y los suyos) esta ban haciendo 35 ". En el curso del relato la actualidad de la praxis política es, llana mente, urgencia de la acción que hará prosperar la insurrección.

$\mathrm{Si}$ puede admitirse que efectivamen te es el intento de dar respuesta a la gran pregunta del Gorgias el que consigue trabar la unidad esencial del tratado Sobre el demon de Sócrates, tendremos que admitir también la relación de su contenido con la vida y los constantes

34 Para más detalles remito a la "Introducción a Sobre la generación del alma en el Timeo", en Plutarco. Obras morales y de costumbres (Moralia), Tratados platónicos, BCG, Madrid, 2004, pp. 87-106.

35 De Genio 576 C. En las razones de Arquias podemos encontrar un eco de la recomendación de Calicles a Sócrates en Gorgias: conviene que los jóvenes se dediquen a la Filosofía y los adultos a la política. Frente a él, Sócrates defendía la atención a la Filosofía por parte de los adultos; recíprocamente los jóvenes conjurados del diálogo de Plutarco, además de sus dis cusiones filosóficas, se disponen a intervenir en los asuntos de la Polis. J. Bo ul o g ne, en su intervención en el Encuentro de la Red Temática sobre Plutarco celebrado en Montpellier los días 29 y 30 de Septiembre de 2000, "A propos de X Adver sus Colotem" constataba que la refutación del epicureismo lleva a Plutarco a incluir en su definición de la "vida buena" la participación en las actividades de la ciudad; en "L'imaginaire politique de Plutarque" demuestra la máxima importancia que concede Plutarco a la actividad política rectamen te orientada, que coloca "au faite du systéme axiologique". 
dilemas que la acción plantea al huma no, una conclusión que, por lo demás, encaja perfectamente con la prioridad práctica que caracteriza la actitud filosó fica de Plutarco. Esta vertiente práctica de su filosofía suele ser destacada en las Vidas por ejemplos concretos de deter minados tipos de conducta; no debería mos olvidar, sin embargo, que Plutarco nos ha proporcionado también la consi deración teórica correspondiente en un pasaje del tratado Sobre si el filósofo de be conversar con los príncipes en el que, partiendo de una cita pindàrica oúk àv-

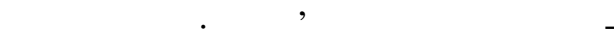

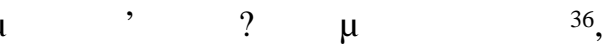
sostiene que el discurso filosófico aspira a hacer eficaz, activo y animado aquello de lo que trate e inculcar impulsos que mueven a la acción y decisiones que apuntan a lo útil, así como elecciones basadas en lo honroso y conciencia de magnanimidad junto con serenidad y constancia $^{37}$. La cuestión que se nos plantea es si estas características que Plutarco exige al discurso filosófico se dan de hecho en las antilogías que apa recen en el tratado Sobre el demon de Sócrates, y en qué sentido mueven a la acción útil y a elecciones moralmente fundadas. Al intentar dar respuesta a esta cuestión será indispensable tener en cuenta las observaciones de A. Pérez Ji ménez quien, al estudiar las motivacio nes de los héroes de Plutarco en las Vidas Paralelas cuando se ven en la tesi tura de tener que elegir entre la utilidad y la justicia, advierte que las inconsis tencias y contradicciones que constata mos entre la adhesión sin fisuras a la Justicia que encontramos en los Moralia y en las reflexiones de índole teórica que aparecen salpicadas en las Vidas y el grado menor en que esto se cumple en las conductas individuales de sus héroes tienen su explicación en la orientación ética y no teorética de sus biografías, que no proponen ideales de perfección, sino ejemplos de comportamientos de personas normales ${ }^{38}$. Esto es de aplica ción al tratado Sobre el demon de Só crates por la doble vertiente, histórica y filosófica, del mismo; más aún, la dis yuntiva entre justicia y acción útil se nos va a presentar en un nivel de dificultad superior en la oposición entre el com promiso con la insurrección de Carón y la inhibición de Epaminondas: el prime ro se implica en la acción útil cuyo obje tivo es la liberación de la patria, que es justa porque la defensa de la patria es un deber primero. El segundo se abstiene en nombre de principios morales y lega les, en nombre de la justicia. En conflic tos de este tipo, dice Pérez Jiménez, "En el primer caso -e. e., cuando está en jue-

Pindaro, Nemeas 5, 1-2.

Sobre si debe el filósofo $776 \mathrm{C}$.

A. Pérez Jiménez, "Los héroes de Plutarco entre la justicia y la utilidad", en L. De Bl o is, J. Boens, T. Kessels y D. M. Sschenkeveld, (eds.), The Statesman in Plutarch's Works, ant. cit., pp. 127-136. 
go la seguridad de la patria- el pensa miento de Plutarco es muy claro: El de ber primero del hombre público es mirar por el bien común, frente a cualquier otro tipo de consideraciones"; pero tam bién constata que Plutarco reconoce ciertos límites al interés público, por ejemplo cuando Camilo renuncia a beneficiarse de la traición del maestro de los niños de los falerios ${ }^{39}$. En nuestro caso, como veremos, Plutarco elogia sin reparos a Carón, pero también deja que Epaminondas se justifique. Es más, cuando, en $594 \mathrm{C}$ éste lo haga personal mente, Plutarco lo autoriza a incluir un motivo de utilidad general en su negati va a participar en la insurrección, que restablece "en quiasmo" la equivalencia moral y patriótica de ambas decisiones: La de Carón se muestra desde el princi pio como útil para la patria $\mathrm{y}$, por eso mismo, justa; la de Epaminondas, que se nos mostraba ante todo como moral y legalmente justa, adquiere ahora esta otra dimensión de la utilidad pública.

Antilogías en la primera parte del relato.

Antes de permitirnos llegar a la sínte sis de los hechos narrados y de las dis cusiones filosóficas referidas, ha sido necesario que estos elementos que, co mo reitera Barigazzi, van alternando desde el punto de vista formal "como los episodios y los cantos corales de una tragedia 40 ", hayan constituido una opo sición para dar lugar a una primera anti logía en la intervención de Teócrito. Empieza éste por contraponer la genero sidad y la valentía espontáneas, naturales, de Carón a la falta de resolución de Epaminondas quien, pese a su excepcio nal educación y sus espléndidas cualida des, se negaba a colaborar con sus amigos conjurados en la empresa de liberar a la patria. Abogando por su hermano, Cafisias replica que la negativa de Epami nondas se refería solamente a la fase ini cial de la insurrección, esto es, a la embos cada contra los oligarcas, a la algarada que previsiblemente seguiría, en la que los conjurados más violentos e impulsivos, además de acabar con los culpables, no iban a dejar pasar la ocasión de asesinar a sus enemigos personales y, posiblemente, también a otros ciudadanos más que se cruzaran en su camino.

La antilogía formada por los juicios de valor de Teócrito, que elogia a Carón y censura a Epaminondas ha vuelto a enlazar con la Antíopa de Eurípides, cu yos personajes enfrentados, Zeto y An fión, habían sido escogidos como repre sentativos de sus propias posturas por Calicles y por Sócrates en el Gorgias platónico. Con ello el adivino nos brinda la ocasión de volver a destacar la in fluencia de este diálogo en el tratado So bre el demon de Sócrates. Hemos visto hace un momento que esta misma anti- 
logia euripidea está en la base del $D e$ gloria; la coincidencia es oportuna por que nos permite medir la distancia que separa el uso de una misma antilogía en un discurso de lucimiento y en un trata do cuya dimensión ética no puede ser ignorada. En efecto, en el tratado Sobre el demon de Sócrates nos vuelve a salir al paso la vieja querella sobre los bioi, pero ésta se plantea ahora muy lejos del tópico escolar, porque ambos extremos de la alternativa han sido ligados a la vida y a la decisión de adoptar una deter minada línea de conducta en la que están en juego cuestiones tan importantes como la libertad de la patria y la legiti midad de los medios para conseguirla.

En este caso la conexión de la antilo gía con la acción no plantea mayores difi cultades; cabe señalar, sin embargo, que, como veíamos en el agon entre Creonte y Hemón, puesto que la insurrección va a implicar, necesariamente, la muerte de un número indeterminado de oligarcas y también de conjurados, esa acción se plantea en el eje en que se enlazan la Vida y la Muerte. Este eje será destacado de nuevo en las alegaciones de Hipostenidas para justificar su decisión de enviar un mensajero a los exiliados para que poster garan su llegada a Tebas:

Si hemos escogido dar prueba a nuestros conciudadanos de valor pa ra arrostrar los peligros y de ánimo para despreciar la vida ..., nos que da todavía gran parte del día (para hacerlo). No esperemos a la noche. Empuñemos las dagas y marchemos contra los tiranos. Matemos y mura mos sin escatimar nuestras vidas. Mas si eso (matar y morir) no es di fícil de hacer o padecer, arrancar a Tebas de tantas armas enemigas co mo la rodean y expulsar la guarni ción espartana al precio de dos o tres muertes no es fácil...

De hecho, desde el principio, la con ciencia del peligro pesa sobre los conju rados en la alarma constantemente reite rada por el temor de haber sido traicio nados o sorprendidos hasta hacerse explícita cuando tenemos noticia de los esfuerzos de Simias para conseguir que conmuten la pena de muerte dictada contra Anfiteo. Desde el punto de vista formal, el sentimiento de riesgo inmi nente se refleja en la composición del relato que transmite eficazmente la angustia, la emoción, el juego de los sentimientos que pasan sin transición de la esperanza al miedo, al desaliento, a la inquietud, a la alegría. Todo esto recuer da la técnica característica de Eurípides, cada vez más acusada al hilo de su pro ducción, con su predilección por las vicisitudes imprevistas y los sobresaltos, las escenas patéticas y las soluciones inesperadas, con la salvedad de que el alcance filosófico que Plutarco quiere imponer a su tratado hace que todos esos recursos se pongan al servicio del juego de luces y sombras de las apariencias y la realidad. Así ocurre, por ejemplo, en el capítulo 4 donde se cuenta que Arquias, uno de los tiranos tebanos y el es partano Lisanóridas, al acercarse a la casa de Simias, han hecho cundir la alar ma en el grupo de los conjurados que 
acababa de hablar con el mensajero de los proscritos; Filidas intenta restablecer la calma al comunicar que ha organizado un convite para que en él los conjurados pue dan apresar con mayor facilidad a Arquias. Más tarde sabremos que tanta angustia carecía de fundamento, porque el motivo que había traído a Arquias y Lisanóridas era que éste, aterrado por la noticia de sig nos y presagios funestos para Esparta, que ría consultar sobre ellos al adivino Teócrito. El temor fundado, como van a probar los hechos, del espartano ha provo cado el de los conjurados que, en el fondo, no es más que reflejo del primero.

La prioridad narrativa que el relato de Plutarco concede a la acción emocio nante queda destacada además por la cir cunspección teórica de las discusiones referidas en esta primera parte del trata do. Por mucho que los asistentes preten dan darles tono filosófico ${ }^{41}$, la mayor parte de las cuestiones tratadas pertene ce al mismo género que las narraciones y noticias de todo tipo que Simias ha conocido en su viaje por tierra de bárba ros. Son $\theta \dot{\omega} \alpha \tau \alpha$, curiosidades que, a pesar de las consecuencias moralizantes que puedan arroparlas, no consiguen auparse a la categoría de consideracio nes filosóficas propiamente dichas. Por ejemplo, en el capítulo 5 nos cuenta la profanación de la tumba de Alcmena, lo que había en ella, la larga inscripción en caracteres extraños cuya copia fue enviada a Egipto para que los sacerdotes dieran su opinión sobre ella. Mientras llega su interpretación nos informan de que los habitantes de Haliartes ven en este crimen, y no en hechos fortuitos, la causa de las calamidades que les ocu rrieron a raíz de dicha profanación y que también los espartanos le atribuyen los presagios recién mencionados. Con la intención de evitar que se cumplan, Lisanóridas se ha acercado a la sepultu ra, encargándose de que se volviera a cerrar y de hacer libaciones. A la vuelta, ha indagado por la tumba de Dirce, cuyo emplazamiento sólo es conocido por los tebanos que han ejercido de hiparcos. Y esto da lugar a una digresión sobre el protocolo de su nombramiento.

En el capítulo 7 llega la información de la lectura que los sacerdotes egipcios dan de la inscripción hallada en la tumba de Alcmena. En ella se ordenaba a los griegos que celebraran juegos en honor de las Musas y que nunca discutieran más que de filosofía. El propio Simias, narrador de estas anécdotas, relaciona esta historia con la del oráculo de Apolo a los delios a quienes anunció que sus desgracias terminarían cuando consi guieran duplicar su altar en Delos. Co mo no conseguían resolver el problema,

En 567 B-C Cafisias, el narrador, advierte al iniciar su relato que el verdadero objetivo de las reuniones en casa de Simias era mantenerse al tanto de los preparativos de la insu rrección y que las "discusiones filosóficas" les servían de tapadera, lo cual es indicio del carácter superficial de esas conversaciones. 
acudieron a Platón para que les ayudara, pero éste, que conocía la interpretación que los sacerdotes habían dado de la ins cripción de la tumba de Alcmena, les contestó que el dios les recomendaba dedicarse al estudio de la geometría y que, con ello, instaba a los griegos a aca bar con las guerras y las desgracias que acarrean, a dar culto a las Musas y a serenar sus pasiones practicando la filo sofía y las ciencias, todo lo cual los capacitaría para tener relaciones benefi ciosas unos con otros.

Todas estas noticias más o menos curiosas nos han apartado del ámbito de las antilogías sofísticas vinculadas a la acción y la vida que aparecían al princi pio de esta primera parte. La primera de ellas surge, como hemos visto, en el jui cio de valor del adivino Teócrito que elogia a Carón y censura a Epaminon das. De esta antilogía nace una cadena ya que su segunda hoja, la censura a Epaminondas, se convierte en primera de otra antilogía cuya segunda hoja co rresponde a la apología que Cafisias hace de su hermano. Cafisias no se de tiene en la negativa de Epaminondas a derramar sangre de sus conciudadanos, una justificación en la que es inevitable detectar el eco de escrúpulos pitagóri cos; prefiere insistir en el valor de la jus ticia en un estado de derecho -no es moral ni legalmente correcto ejecutar a un ciudadano sin juzgarlo ${ }^{42}$-, pero orga niza su argumento de tal modo que su giere otra dimensión de la justicia, la que impone en la ciudad platónica que los fi lósofos gobiernen y que los auxiliares sólo actúen a las órdenes de los prime ros. Y esta relación quedaría invertida si Epaminondas se hubiera sometido a las decisiones de los conjurados.

La evocación de la República que se percibe en las palabras de Cafisias puede tener un precedente en la oposición que Teócrito había establecido entre la con ducta de Carón y la de Epaminondas, porque los reproches que formula contra éste entroncan con las razones en las que Platón se amparaba para arrancar a sus filósofos de la beatitud alcanzada en la pura contemplación de las Ideas y com prometerlos en el gobierno de la ciudad. La impresión que nos queda es que si Epaminondas fuera realmente el "Sócra tes beodo" que alguna vez se ha visto en él, ya habría superado la fase de la aseesis que su elogio de la pobreza confiesa más adelante ${ }^{43}$; si hubiera llegado ya al nivel de conocimiento requerido para ser un filósofo rey, le hubiera correspondido decidir el tipo de acción que había que adoptar. Los reproches de Teócrito vie nen, de este modo, a desplazar la cues tión de la oposición de los bioi a este

42 En este punto Epaminondas se acerca a Sócrates en el juicio de los generales de las Arginusas. Sócrates no se conforma con la celebración de un juicio, exige además, que sea un juicio justo.

43

De genio 584 D- $585 \mathrm{D}$. 
otro plano del proceso de la dialéctica platónica para darnos a entender que Epaminondas está todavía avanzando por la fase ascendente. En ello tenemos un primer indicio de la transposición a la que Plutarco va a someter la antilogía sobre los tipos de vida. Esta transforma ción es esencialmente producto del de bate sobre el demon de Sócrates, la cues tión filosófica central en este tratado.

Por ahora, reduciendo lo anterior a esquema, tendríamos

\section{Ia antilogía: Teócrito}
a) generosidad de Carón
b) negativa de Epaminondas

\section{2a antilogía}
a) = censura de Epaminondas por Teócrito
b) apología de Epaminondas por Cafisias.

3a antilogía: apología de Epaminondas basada en la sumisión a la justicia

a) nivel prefilosófico (aspectos ritual y legal)
b) nivel filosófico: justicia política de la República platónica, e. e., que gobierne el filósofo.

Intermedio: la llegada de Teánor.

Tras el paréntesis del capítulo 7, de sabor anticuario, el capítulo 8 nos devuelve a los hechos actuales. Empieza por referir la llegada de Teánor, un pita górico que, guiado por sus sueños, ha venido de Italia para hacer libaciones so bre la tumba de Lisis, un anciano, tam bién pitagórico, que tuvo que emigrar cuando las persecuciones contra la secta. Se refugió en Tebas y allí aceptó como discípulo a Epaminondas quien, des pués, lo cuidó en su vejez y lo mandó enterrar cuando murió.

Con la llegada de Teánor se inicia la elevación del nivel filosófico de la con versación que pasa a debatir un proble ma ético: el extranjero traía encomenda da una doble misión, trasladar a Italia los restos de Lisis si el demon del difunto no se oponía a ello y entregar cierta canti dad de dinero a la familia de Polimnis como recompensa a su generosidad para con Lisis. Pero tanto Polimnis como sus hijos, Epaminondas y Cafisias, se niegan en redondo a aceptarla. Esto da lugar a un debate que se suele considerar como un agon sobre la riqueza y la pobreza, una antilogía en la que Teánor no defien de tanto la virtud de la riqueza cuanto el deber de gratitud del amigo rico para con su amigo más pobre que ha sabido ser generoso a pesar de sus escasos recursos. Del mismo modo, más que elo giar la pobreza, Epaminondas insiste en justificar su negativa a aceptar una ganancia legítima aduciendo la necesi dad de ir preparándose a luchar contra la 
tentación de beneficios injustos. El con tenido ético de esta discusión es traicio nado por el acartonamiento retórico que lo convierte en tema de argumentos demasiado alambicados; frente a la "seriedad y urgencia" en las que la desa fortunada expresión de Ch. L. Stevenson cifra la implicación del sujeto que enun cia un juicio moral ${ }^{44}$, la frialdad del alar de retórico nos coloca ante una elección que no nos afecta porque el carácter escolar de la antilogía ha vuelto a sepa rarla de la vida.

Entre el anuncio de la llegada de Teánor y de la doble misión que lo ha traído a Tebas y su presencia en casa de Simias se ha iniciado el debate sobre el demon de Sócrates, que, a su vez, es interrumpido cuando, al empezar el capítulo 13, Epaminondas y Teánor se suman a la reunión y sostienen el agon sobre la riqueza y la pobreza que acaba mos de comentar. Tras este debate Teá nor informa sobre su visita a la tumba de Lisis; refiere que "una voz" le ha comu nicado que el cuerpo del difunto debe seguir enterrado en Tebas, que su alma había sido juzgada y unida a otro demon para una nueva encarnación y su demon atribuido a otra persona. El momento era idóneo para recuperar la cuestión del demon de Sócrates, pero una serie de imprevistos en los planes de los conjura dos van a retrasarlo de nuevo al requerir la presencia de Carón, Teócrito y el pro pio narrador en este otro frente. Cuando, en el capítulo 20, Teócrito y Cafisias regresan junto a Simias, los demás habí an recuperado ya el tema; al parecer lo que Cafisias no pudo oír fue la réplica de Simias a los argumentos de Galaxidoro, aunque tuvo información de ella en otro momento.

\section{El debate sobre el demon de Sócrates}

No puede ser casual el que también ese debate, dividido en dos secciones que separan la llegada de Teánor y su discu sión con Epaminondas y las novedades en los preparativos de la insurrección a las que acabamos de aludir, se estructure como una antilogía que, a su vez, com prende una guirnalda de otras más.

\section{Primera sección}

La noticia de que Téanor va a con sultar al demon de Lisis sobre el even tual traslado de su cadáver da ocasión a la violenta intervención de Galaxidoro que inicia esta primera parte del debate con la oposición, sostenida por tajantes juicios de valor, entre superstición y fi losofía, caracterizadas como irracionali dad y racionalidad ${ }^{45}$. Sobre esta base, di ce Galaxidoro, los filósofos que, como los pitagóricos o como Empédocles, pre-
44

45

Ch. L. St evenson, Ethics and Linguistics, Yale University Press, 1944.

Al mismo tiempo, aunque en otro plano, Galaxidoro opone a la superstición la vanidad y a la filosofía la política sobre la cual pesan implícitamente los reproches que contra ella formulaba Sócrates en el Gorgias, e. e., que persuade sin enseñar. 
fieren recurrir a oráculos, fantasmas, sue ños o fábulas antes que a demostraciones rigurosas, traicionan la filosofía que pre tenden servir. Frente a ellos Galaxidoro propone el ejemplo de Sócrates que se basaba en su recio sentido común y en la razón para cultivar una filosofía que sólo se atenía a la realidad. Notemos, ante todo, que las oposiciones de Galaxidoro participan de la querencia por la acción y la vida que nos ha servido para caracteri zar las antilogías sofísticas, porque el defensor del racionalismo a ultranza no pretende tan sólo que se acepte su punto de vista como un planteamiento teórica mente plausible, sino, además, que esa aceptación implique la de una línea de conducta cuyo mejor ejemplo encuentra en la persona de Sócrates.

En cuanto a la antilogía que opone los dos modos de abordar la filosofía, cabe constatar que repite el movimiento que hemos visto antes en los juicios de valor de Teócrito: el racionalismo de Sócrates se convierte en la primera hoja de una nueva antilogía cuyo segundo término, introducido por Teócrito, será el famoso demon que guiaba a Sócrates, iluminándolo en las cuestiones que superan la sabiduría humana. Esto dará lugar a un nuevo contraste de pareceres: Galaxidoro intenta dar una explicación racionalista al interpretar el demon co mo un impulso a su razón que Sócrates obtenía de un estornudo o algún otro ruido en situaciones concretas "oscuras y que no dan base a un cálculo razona ble". La situación en la que Galaxidoro considera la eficacia de esos ruidos des

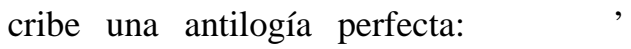

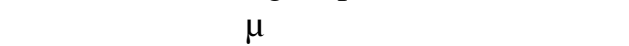

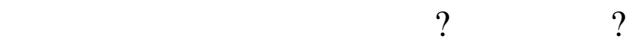
$\dot{\alpha} v \alpha 1 \rho \varepsilon \theta \varepsilon i \sigma \eta{ }^{24}$. Al mismo tiempo, la mención a estos ruidos ha abierto otra antilogía cuyo segundo término es ahora una ó $\psi 1$ ?, una capacidad de visión que el adivino Teócrito interpreta como clarivi dencia que "arrojaba luz" sobre esos problemas ${ }^{47}$, aunque al concluir la frase

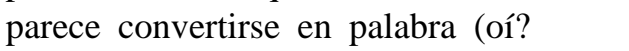

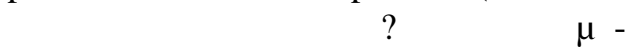

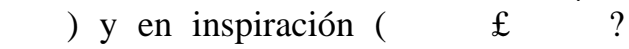

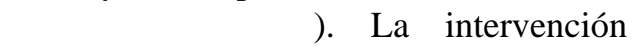
de Polimnis supone la adición de un ter cer elemento a la antilogía básica: como los nobles persas en la discusión de las constituciones políticas que refiere $\mathrm{He}$ ródoto, empieza por rechazar las tesis de Galaxidoro que relaciona con la Escuela de Mégara: el demon de Sócrates no era ni un estornudo ni un ruido, porque él no atribuía sus decisiones a estas circuns tancias fortuitas, sino a su demon; y la de Teócrito: no era Sócrates una veleta cuya conducta fuera constantemente alterada por circunstancias exteriores, sino que sus impulsos tuvieron siempre el rigor inflexible que demuestra la constante orientación de su vida, fruto

\section{De genio 581 A.}

${ }^{47}$ Esta concepción de la vista como rayo de luz que va del ojo al objeto es la que Platón defiende en Timeo. 
de una decisión razonada. Finalmente expone su propia opinión: la vida de Sócrates demuestra que "la autoridad de un principio superior lo guiaba a la vir tud". Tras esto, parece que Galaxidoro llega a una solución de síntesis cuando concluye que, bien mirado, los estornu dos y ruidos eran los instrumentos de ese poder sobrenatural, aunque esa solución nos deje a oscuras sobre la naturaleza y los poderes del demon ${ }^{48}$.

La llegada de Teánor interrumpe esta discusión a la que, sin proponérselo, hará una importantísima contribución, la no ción pitagórica del demon personal. Esta es introducida sin explicaciones previas en el relato que hace Teánor de su consul ta ante la tumba de Lisis: En vez de la visión que, presumiblemente, esperaba dice que le pareció oír una voz que lo di suadió de su intención de llevarse los res tos y le comunicó que el alma de Lisis ya había sido juzgada y unida a otro demon para un nuevo nacimiento. Esto implica que cada alma cuenta, en cada vida, con la asistencia de un demon ${ }^{49}$.

La urgente necesidad de intervenir para remediar contratiempos imprevis tos de los conjurados ha obligado a Cafisias, el narrador del diálogo, a ausen tarse cuando Simias se disponía a repli car a los argumentos de Galaxidoro. Cuando se reincorpora a la reunión, $\mathrm{Si}$ mias está rememorando sus recuerdos de Sócrates; concretamente, está diciendo que el filósofo despreciaba a quienes pretendían tener comunicación con lo divino por medio de visiones ${ }^{50}$, mientras que prestaba la mayor atención a quie nes decían haber oído una voz sobrena tural. La explicación de la naturaleza de la voz y de su modo de afectar la sensi bilidad, la misma que ofrece Platón en el Timeo $^{51}$, permite a Simias plantear que el demon podía comunicar su pensa miento directamente, sin voz, al nous de
48

49

Más adelante (588 C) Simias cuenta que en cierta ocasión preguntó a Sócrates por la ov бi $\alpha$ y la $\delta \dot{v} v \alpha 1 *$ de su demon, pero que no le contestó.

Teánor concluye su exposición sugiriendo que el mismo demon que había guiado a Lisis asiste a Epaminondas, sin precisar si es que un mismo demon puede asistir a más de un alma simultáneamente -lo cual parece contradictorio con lo que dijo la voz- o si puede haber sustitución de un demon por otro en un alma en el curso de una misma vida.

50 El comentario, que replica a la idea de la ó $\psi 1 *$ expuesta por Teocrito, no parece muy oportuno teniendo en cuenta la presencia de Teánor que ha venido guiado por sus sue ños. Además contradice lo que le ocurre al propio Sócrates al principio del Critón y la noticia que, en $594 \mathrm{E}$, nos proporciona el propio Cafisias cuando refiere que, al entrar en la ciudad, algunos de los exiliados vieron resplandecer, a la derecha, un relámpago sin trueno, que interpretaron como señal favorable. Por otra parte la visión tiene gran impor tancia en los mitos escatológicos de Plutarco; sobre esto remito a F. E. Br enk, por ejem plo, en 'The Origin and the Return of the Souls in Plutarco", en M. García Val dés (ed.), Estudios sobre Plutarco: ideas religiosas, Madrid, 1994, pp. 3-24.

51 Platón, Timeo 67 a; esta explicación aparece de nuevo en Aristóteles, De anima 2,8,420 b 29. 
Sócrates, una especie de transmisión del pensamiento que Plutarco compara con lo que ocurre en los sueños: el sujeto cree que oye hablar cuando, en realidad, no hay voz ; esta idea puede estar anticipa

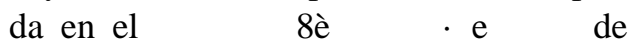
Teánor. El largo parlamento de Simias abunda en ecos de las teorías de la per cepción y de los movimientos que el alma decide que realice el cuerpo expues tas por Platón en el Timeo; este cúmulo de datos y explicaciones científicas tiene como primer objetivo el servir de base para que, por analogía, admitamos que

un espíritu puede ser guiado por un espíritu superior y un alma por otra más divina que entra en con tacto con ella desde fuera, del mismo modo que la razón entra en contacto con otra razón como la luz con su reflejo.

$\mathrm{Y}$, en segundo lugar, que considere mos todo esto como la explicación racional que "endereza" la de Galaxidoro, lo mismo que en el Fedro platónico el primer discurso erótico de Sócrates "enderezaba" el de Lisias. Esto nos avi sa que, tras esta explicación racional, hemos de esperar otra que corresponda al segundo discurso de Sócrates. En el De genio esperamos ahora una explica ción que atienda al costado irracional del demon, esto es, un nuevo discurso que cierre la antilogía iniciada por el conjun to de la explicación racional de Galaxidoro y esta otra de Simias. A la segunda hoja de esta antilogía corresponde el Mito de Timarco 5253 .

Timarco bajó a la gruta de Trofonio para consultar al oráculo sobre un tema concreto, los poderes del demon de Sócrates, pero una voz celeste ${ }^{54}$, la del demon que lo guiaba, va a darle una infor mación diferente: sin nombrar siquiera a Sócrates, va a ir describiendo una escato logia de las almas en las que se inserta una demonologia. Este cambio de tema es con secuencia de la respuesta del protagonista a la pregunta de la voz: "¿Qué quieres saber?", 'Todo". Un todo que, así hay que admitirlo, se va a restringir al feudo de Perséfona, un universo cuyos principios ontológicos son la Vida, el Movimiento, la Generación y la Corrupción, encargados de recordamos que no hemos salido del ámbito del Devenir ${ }^{55}$.

Este pasaje ha sido estudiado por L. Van der St ockt, Twinkling and twilight. Plutarch's reflections on literatura, Bruselas, 1992, $\rho$. 57-58: la comunicación directa, sin voz ni palabras del demon al alma del humano revela la deficiencia del lenguaje humano que, al tener que recurrir a la mediación del lenguaje articulado, no es más que un reflejo de la auténtica comunicación.

El propio Simias da testimonio de la nueva dimensión de su relato en 589 A: "Pero el relato de Timarco... quizás parezca más un mito o una ficción que una historia real".

54 Timarco no ve en ningún momento a su guía, tan sólo lo oye.

55 El mito de Timarco no incluye el nivel platónico superior, un aspecto estudiado en pro fundidad con respecto al tiempo por F. E. Br enk, "Tempo como struttura nel dialogo Sul 
La descripción del feudo de Perséfona nos suministra, entre otras muchas noticias, información sobre la naturaleza del alma, sobre la de los démones, sobre las relaciones entre ambos y sobre ese famoso vínculo que une al demon con el alma y que, en el caso de almas cuya obediencia al demon es innata, que son las de los adivinos y hombres inspirados, pueden incluso, por indicación del de mon, aflojar el vínculo y permitir que aquél deambule por el mundo exterior, y comunique después al alma todas las cosas interesantes que ha visto y oído en su vuelo ${ }^{56}$. Vemos así que la oposición lingüística que define como dos entidades diferentes el alma y el demon debe ser precisada en el sentido de que el alma es el término que suele designar al conjunto constituido por el elemento inferior, com patible con el cuerpo y susceptible de ser dominado por el cuerpo y las pasiones, y el elemento superior, el espíritu, que, en realidad, es un demon y que, aunque el común de los humanos lo considera inte rior, en verdad es exterior, ajeno al hom bre. Las relaciones entre estos dos ele mentos son descritas por medio de una serie de imágenes que derivan directa mente de la comparación platónica del al ma con un carruaje alado ${ }^{57}$, tan conocida que no voy a detenerme ahora en ella, para destacar, en cambio, que el mito de Timarco afirma, para cada humano, la asistencia de un demon al que tenemos que aprender a obedecer.

Invitado a pronunciarse sobre este mito, Teánor pasa por alto la identifica ción del espíritu y el demon que hubiera podido plantear dificultades desde el pun to de vista de la escatología pitagórica, pe ro sí que recupera la oposición de las dos realidades distintas, que enlaza con la tra dición hesiódica, de acuerdo con la cual los démones son las almas de algunos difuntos ${ }^{58}$ y les encomienda la misión, no de vigilar a los vivos, como en el mito de Hesíodo, sino de ayudar con sus consejos a aquellos humanos cuya virtud pugna por el mismo objetivo que había sido el del demon antes de morir ${ }^{59}$.

daimonion di Socrate di Plutarco" en G. D'Ippol it o e I. Gallo (eds.), Strutture formali dei Moralia di Plutarco, ant. cit., pp. 69-89. Una segunda versión de este trabajo apare ce en Relighting the Souls, Stuttgart, 1998, pp. 59-81. Por su parte, J. Boulogne, "L'imaginaire politique De Plutarque" encuentra en el imaginario que se deduce de este mito, del De sera y del De facie el fundamento metafísico de valoración que hace Plutarco del empeño de Alejandro y del imperio de Roma.

56 El demon que guía a Timarco corrige, de este modo, la interpretación usual de los vue los astrales: no es el alma la que abandona interinamente el cuerpo, sino el demon el que se libera, en cierta medida, del alma.

Platón, Fedro 246 a-b.

58 También en el De facie 944 E, las almas de los muertos son démones que administran los oráculos, asisten a los Misterios, vengan los crímenes y salvan de los peligros.

59 En esta afinidad podemos ver un nuevo eco del Fedro platónico, en este caso del pasaje 252 c- 253 c en el que Sócrates explica el temperamento de los hombres de la primera 
Intentando reducir a un esquema el oponentes Teócrito y Polimnis- y los debate sobre el demon de Sócrates pode mos constatar una antilogía global entre los argumentos de Galaxidoro -y sus argumentos de Simias. En ambos casos una intervención de Teánor funciona como estrambote.

\section{Sección A: argumentos de Galaxidoro}

I a antilogía: modos de abordar la Filosofía

a) superstición, irracionalidad, pitagóricos y Empédocles.

b) Filosofía, racionalidad, Sócrates

2a antilogía: Teócrito

a) racionalismo de Sócrates afirmado por Galaxidoro.

b) el demon de Sócrates.

$3^{\text {a }}$ antilogía: Galaxidoro

a) niega poder extraordinario y premonitorio del demon

b) interpretación racionalista de Galaxidoro

c) teoría de la ouı de Teócrito

4⿳a antilogía: Polimnis

a) crítica a la escuela de Mégara ${ }^{60}$; Sócrates no atribuía sus impulsos a los estornudos, etc., sino al demon.

b) Tesis de Polimnis: el rigor razonado de la conducta de Sócrates in dica que lo guiaba un espíritu superior.

Solución de síntesis de Galaxidoro: estornudos y ruidos eran instrumentos

$\lambda$

de ese poder superior.

Contribución de Teánor: noción de demon personal, (a propósito del demon de Lisis).

\section{Sección B: argumentos de Simias}

I. Argumentos racionalistas, en antilogía con la síntesis de Galaxidoro

Ia antilogía: réplica que no conocemos a Galaxidoro

2a antilogía: aplicación de la anterior: recuerdos de Sócrates

a) desprecio de las visiones

b) valoración positiva de la voz.

$3^{\text {a }}$ antilogía: la comunicación

a) verbal: la voz, naturaleza y modo de afectar la sensibilidad

b) comunicación sin palabras ('endereza" la síntesis de Galaxidoro).

II. Argumento suprarracional: Mito de Timarco.

Contribución de Teánor: un demon guía a cada hombre.

generación de cada ciclo de encarnaciones por el dios en cuyo cortejo en el que se inte graba su alma antes de la caída; explica asimismo la atracción amorosa entre el amante 60 y el amado por el hecho de haber formado parte sus almas del cortejo de un mismo dios.

Tal como la describe Polimnis la interpretación que hacían en la Escuela de Mégara de la actitud de Sócrates ante la señal divina es una exageración paródica de la interpreta ción racionalista de Galaxidoro. 


\section{La insurrección}

El debate filosófico nos ha enseñado que un demon nos asiste a lo largo de nuestra vida y que en nosotros está el sa ber prestar atención y obedecer a sus indicaciones. Los episodios narrativos sobre la puesta a punto del plan de la insurrección (capítulos 17-19) y de la ejecución del mismo hasta culminar en la liberación de la ciudad pueden ser considerados ahora a la luz de lo que he mos visto en el debate filosófico.

Estos pasajes contienen ejemplos de sucesos que son mal interpretados al uní sono por los conjurados. Así, la alarma creada por la presencia de Arquias y Lisanóridas en la primera parte, injustifi cada como hemos visto, encuentra su pa ralelo en la última: Estaba ya Teócrito celebrando el sacrificio previo a la ejecu ción del plan cuando llamaron a la puerta dos servidores de Arquias que conmina ron a Carón a presentarse inmediatamente ante el tirano. Esto produjo gran conmo ción entre los conjurados que se creyeron delatados; empezaron a hacer elucubra ciones sobre el posible traidor, Hipostenidas sin duda, que ya antes había intentan do retrasar la llegada de los exiliados... En todo caso, lo incuestionable es que Carón tiene que presentarse ante los magistrados. Se despide de sus amigos con palabras llenas de magnanimidad y nobleza, como para afrontar la muerte. En garantía de que no va a traicionar a sus amigos, a quienes arenga a continuar va lientemente con el plan previsto, entrega como rehén a su propio hijo. No bien hu bo salido Carón llega Cefisodoro y, al en terarse de lo ocurrido, apremia a los demás a precipitar el ataque antes de que los adversarios pudieran tomar medidas para desbaratar el plan de insurrección. El adivino Teócrito apoya su propuesta por que el sacrificio que acababa de hacer ha bía salido bien y garantizaba la seguridad de los implicados. Estaban ya armándose cuando regresa, sano y salvo, Carón y re fiere que solamente han llegado a los tira nos rumores imprecisos. Entonces, tras dirigir una plegaria a los dioses, se ponen todos en marcha.

Como vemos, en este emocionante relato hay hechos cuyo alcance malinterpretan al principio y señales - el sacrificiocorrectamente interpretadas. Al coincidir todos en la interpretación de los hechos y aceptar, como no podía ser menos, la del adivino sobre el sacrificio, no hay lugar en este episodio para planteamientos antilógi cos. Semejante es desde este punto de vista el caso que nos brinda el capítulo 26: algu nos de los exiliados, que están entrando en pequeños grupos en la ciudad, amparados por la caída de la noche y por el frío y el viento que habían metido a la gente en casa antes que de costumbre, vieron, al traspasar las puertas de la muralla, res plandecer a su derecha un relámpago sin trueno. Lo interpretaron como una favora ble señal de seguridad y gloria, porque entendieron que vaticinaba que la empresa sería brillante y exenta de peligro.

Más interesante resulta para nuestro tema el caso de contraste de pareceres sobre un acontecimiento y una señal que 
Cafisias expone circunstanciadamente. Este episodio tiene lugar después de la exposición de Teánor sobre la cuestión de la tumba de Lisis: Llega a casa de Simias Fílidas con Hipostenidas, llama aparte a Carón, a Teócrito y a Cafisias y los pone al corriente de que Hipostenidas, con el fin de retrasar la llegada de los exiliados, les ha enviado a un hombre a caballo para detenerlos. Fílidas y Carón reconvienen a Hipostenidas. Éste se defiende dando lugar a una primera antilogía; entre las razones que ofrece Hipostenidas para jus tificarse encontramos

a) Un primer bloque de argumentos lógicos, basados en datos objetivos: una cosa es emborrachar a Arquias y demás invitados al convite de Fílidas $\mathrm{y}$ otra bien distinta son los mil qui nientos hombres de la guarnición, sin contar con Herípidas y Árquesos, que, ellos, no estarán bebidos.

b) Un segundo bloque de argumentos ba sados en apreciaciones subjetivas: los enemigos deben estar al tanto del re greso de los exiliados, de modo que su llegada ahora implicaría su muerte. Indicios de que los enemigos están al tanto: Primero, los de Tespias han reci bido orden de estar alertas, armados y dispuestos a acudir en cuanto se lo in diquen los jefes de los espartanos. Se gundo, están interrogando a Anfiteo y, por lo que se dice, lo van a ejecutar en cuanto regrese Arquias ${ }^{61}$. c) Un tercer bloque de argumentos no racionales que comprende

- un argumento religioso: los adivi nos que están sacrificando un buey a Démeter anuncian un gran albo roto y peligro para nuestro pueblo.

- Interpretación de un sueño: Hipatodoro, un vecino que no estaba al tan to de los planes de insurrección, le pidió que le contara a Carón un sue ño, alarmante y extraño, que había tenido y que, a su juicio y al de $\mathrm{Hi}$ postenidas, era premonitorio de peli gro para Carón. Soño que la casa de éste tenía dolores de parto y que, mientras Carón y los suyos, inquie tos, formaban círculo en tomo a ella rezando, la casa mugía y profería vo ces inarticuladas; por último, res plandeció desde su interior un fuego imponente que prendió la mayor parte de la ciudad, aunque Cadmea, la ciudadela, sólo estaba envuelta en humo, porque el fuego no llegaba hasta arriba. La interpretación de $\mathrm{Hi}$ postenidas es que el sueño de su ve cino presagia un gran peligro para los conjurados, que tienen el apoyo del pueblo, mientras que a los tira nos, que dominan la ciudadela, no les pasará nada grave.

Esperaríamos réplicas antilógicas a cada uno de los tres bloques, pero, evi tando un esquematismo excesivo, pasar a su casa en cuanto llegó, con el acicate de la presencia de cierta mujer casada. 
Plutarco permite que Teócrito le corte la palabra a Carón que, presumiblemente, se disponía a contestar a los dos primeros. Como era de esperar, el adivino sólo con testa al último, que es el que tiene que ver con el ámbito de sus competencias. Lo hace en un esquema de composición anu lar en el que el argumento religioso ocupa el principio y el final. Así tenemos

a) frente al sacrificio que están cele brando los adivinos en el santuario de Démeter, los muchos que él ha cele brado y que han dado siempre resul tados favorables a los exiliados.

b) la interpretación del sueño por parte de Hipostenidas y su amigo es erró nea. La suya es que

- el fuego que resplandece desde una casa amiga (ex silentio es un presa gio favorable para su dueño) mien tras que la vivienda de los enemi gos ha quedado tiznada por el humo, que nunca anuncia más que lágrimas y disturbios.

- las voces inarticuladas que profería la casa indican que, aun en el caso de una eventual delación, la empre sa sólo será objeto de rumores im precisos y vagos y no será conoci da más que cuando triunfe.

c) volviendo a los funestos presagios del sacrificio celebrado en honor de Démeter, los justifica porque no se han celebrado en nombre de la ciu dad, sino de los tiranos.

Aunque la réplica de Teócrito no afec te más que al tercer bloque de los argu mentos de Hipostenidas, ha liquidado, de hecho, el conjunto de los mismos; por eso Cafisias puede volver ahora a la decisión de enviar un mensajero a los exiliados, para intentar remediarla. Hipostenidas se muestra pesimista, porque su enviado tiene el mejor caballo de la ciudad. Para su sorpresa, al alzar la vista, ve a su hom bre apoyado en el quicio de la puerta. Cariacontecido informa de que no ha podido cumplir su misión porque su mujer le había prestado las riendas a un vecino $y$, en vez de decírselo enseguida, le

ha hecho perder tiempo haciendo como que las buscaba; se han peleado...

La iniciativa de la mujer de Clidón ha funcionado como un elemento fortuito que ha anulado la desafortunada deci sión de Hipostenidas. Volvemos a la si tuación anterior. La percepción de la urgencia de la acción se traduce en desa zón y ansiedad para quienes han de ser sus protagonistas.

\section{Conclusión}

Esta revisión de los argumentos con los que Plutarco intenta justificar la decisión de Epaminondas de abstenerse de intervenir en la insurrección, valoran do a la vez muy positivamente a los con jurados, y de los razonamientos con los que procura dar cuenta del impulso de un elemento irracional en el hombre más racional debería autorizamos a poner las bases de una conclusión.

Resulta evidente que, al margen de su sumisión a las normas escolares, predo minante en las obras de juventud, pero 
también presente, aunque más mitigada, en las de madurez y de vejez, -en este mismo diálogo tenemos el "agon entre la riqueza y la pobreza"- Plutarco se dejó influir por las antilogías sofísticas, cuya afinidad con la acción y la vida concuerdan perfectamente con la dominante ética de sus preocupaciones didácticas tanto en las Vidas como en los Moralia.

Por otra parte, su sincera adhesión a los planteamientos éticos de Platón lo lleva a realizar una transposición jerár quica en razón de la cual deshace la apa rente equivalencia de las dos tesis opuestas en las antilogías de los sofistas para, gracias a la afirmación de un $\kappa \rho E i \tau \tau \omega \nu \lambda$ ójo mística, ya que no filo sóficamente fundamentado, volver a tra zar la curva del proceso dialéctico. En ésta la fase de la bajada puede ser considerada como la síntesis de la acción que corres ponde al tramo de la ascensión y de la fase contemplativa, puesto que en la bajada la acción queda subordinada a la intuición que la decide y determina. Para poder aplicar al De genio esta síntesis conviene poner en relación las articulaciones de este tratado con el símil platónico general mente conocido como el mito de la caver na en el que Platón describe gráficamente la diferencia entre la ascensión hacia el conocimiento del Ser y del Bien, la intui ción mística y el regreso a la caverna que simboliza el mundo del tiempo y de la acción, el mundo del devenir en el que se desarrollan nuestras vidas.

62 Cf. De genio524 D-E.

${ }^{63}$ Cf. De gen B-C
En otros términos, creo que el $D e$ genio la exposición escatológica es la que permite evaluar los hechos y las conductas; que la explicación del mito de Timarco que ofrece Teánor es la que nos capacita para ver en el encadena miento de las circunstancias fortuitas -la carta que Arquias no lee, pero cuya lec tura le hubiera salvado la vida y habría arruinado la posibilidad de que la insu rrección saliera adelante; el mensajero que, alarmado por el sueño de un amigo, mandó Hipostenidas con el fin de apla zar la llegada de los exiliados y que no pudo llevar a cabo su misión por una futilidad, etc.- como otras tantas inter venciones de los démones terrestres en ayuda de los conjurados ${ }^{62}$.

Podría, incluso, sospecharse que Plu tarco intentó, al establecer la estructura de este tratado, seguir las fases del pro ceso dialéctico. En efecto, tenemos, en primer lugar una clara prioridad de la acción que es explícita al principio del tratado, cuando Cafisias reconoce que el verdadero objetivo de las reuniones de los conjurados en casa de Simias era ir acordando las medidas que las circuns tancias fueran requiriendo y que las dis cusiones filosóficas sólo eran tapadera del fin pragmático ${ }^{63}$. En segundo lugar aparece el mito de Timarco como corre lato de la intuición mística -con la sal vedad, ya señalada de que no abandona mos el feudo del Devenir- $y$, por último, 
los avatares de la insurrección propiamen te dicha, que nos vuelven a llevar al ámbi to del tiempo y la acción, como la vuelta a la caverna en la bajada dialéctica.

En cuanto al tema que da nombre al diálogo, el de la naturaleza del demon de Sócrates y sus poderes, no encontramos una respuesta racional y científica -al parecer imposible, puesto que Sócrates no contestó a la pregunta de Simias-, sino mística, que es la que proporciona el Mito de Timarco en el que, como hemos visto, el demon que guía al consultante no men ciona a Sócrates. Lo que podemos deducir de este mito y de las precisiones al mismo que debemos a Teánor es que el demon de Sócrates es similar al que acompaña a ca da humano a lo largo de su vida. No queda claro, en cambio, si ese demon personal es el alma de un difunto, como sugiere la adaptación que hace Teánor de la exposi ción hesiódica, o si es un ser superior de otra naturaleza. Queda claro, en cambio, que nos guía y aconseja con sus indica ciones; que las almas de los adivinos y hombres inspirados tienen innata capaci dad para percibir sus indicaciones; que Sócrates contó, desde niño, con esa capa cidad en grado elativo, mientras que en el común de los mortales está en función del grado en que cada cual haya conseguido equilibrar su alma. Por su parte, los episo dios narrativos nos muestran que la mayo ría de los hombres perciben como hechos excepcionales los que lo son y como seña les de un poder superior las que asimismo lo son. El problema es su interpretación: los exiliados aciertan al interpretar el re lámpago sin trueno, pero Hipostenidas y su amigo yerran por completo en la interpre tación del sueño de este último.

En cuanto a la pregunta que nos hací amos sobre si las estructuras antilógicas "sofísticas" que abundan en este tratado cumplen el cometido que Plutarco exigía al discurso filosófico en Sobre si el filó sofo debe conversar con los príncipes de mover a la acción útil y a elecciones mo ralmente fundadas, podemos ver que ambos objetivos se disocian en la prime ra cadena: ante el dilema de participar o no en la insurrección, Carón ha optado por la acción útil y Epaminondas por las restricciones morales. Sin embargo, el desarrollo de la acción va a demostrar que ambas decisiones son necesarias, que, cada uno en su momento y de acuerdo con su temperamento, Carón y Epaminondas son indispensables para asegurar un mañana mejor, porque la pa tria será libre, pero también mejor, por que será factible la reconciliación de los ciudadanos. Este argumento, ausente en la apología de Cafisias, es aducido por Epaminondas cuando, justo antes de que los conjurados emprendan la acción a la que él mismo los alienta, rechaza, por última vez, intervenir en ella: Es menes ter que haya un grupo de personas no implicadas ni con los tiranos ni con los sublevados que puedan servir de nexo para reconstruir la unidad quebrada ${ }^{64}$. 
La segunda cadena de antilogías ver tebra el debate sobre el demon de Sócrates; el tema, más abstracto y teóri co, parece, en principio, alejarnos de "la acción útil", aunque, en realidad, lo que pasa es que la acción útil se considera ahora en un nivel general: No se trata ya de decidir, ante un dilema puntual, qué conducta concreta conviene adoptar, sino de hacer la gran elección que com promete el sentido de nuestras vidas, una elección racional, porque es la razón la que tiene que definir la meta a la que debemos aspirar y cada uno de los pasos que conducen a ella. Este es el momento en que intervienen los planteamientos antilógicos (en diálogo con otro o, como dice Platón, en diálogo del alma consigo misma). Pero, como reconoce incluso Galaxidoro, el defensor del racionalismo a ultranza, hay situaciones en que la equivalencia de las alternativas es tan apurada que la razón humana no puede decidir por sí misma. En estos casos Sócrates decidía en función de la famo sa señal que le hacía su demon. La natu raleza de esa señal, es irrelevante: puede tratarse de visiones (contra Simias), o de voces, pero también de transmisión del pensamiento por parte del demon a la persona que tutela. El problema para ésta reside, por tanto, en identificar e interpretar correctamente esas señales. Mientras los adivinos, hombres inspirados y Sócrates tienen innata esa capacidad, los demás tenemos que ir conquistándola a base de reprimir las pasiones, de autoconocimiento y de constante tensión hacia el bien; el progreso que cada cual haga en este proceso determinará la utilidad de cada una de sus acciones y garantizará el mayor o menor fundamento moral de sus elecciones. En otros términos, esto es lo que anticipaba ya el análisis que Polimnis hacía en 581 A-D de la doble raíz de la conducta de Sócrates: la constante orien tación de su vida, fruto de una decisión razonada y "la autoridad de un principio superior que lo guiaba a la virtud".

En suma, también en este diálogo, que parece yuxtaponer dos relatos indepen dientes, el de los hechos históricos que condujeron a la liberación de Tebas y el de las conversaciones filosóficas sobre el demon de Sócrates, se produce esa "union harmonieuse de la raison et de la foi" que en opinion de Fr. Frazier, constituye el corazón del pensamiento de Plutarco ${ }^{65}$. de Plutarco celebrado en Montpellier, 29 y 30 de Septiembre de 2000. 